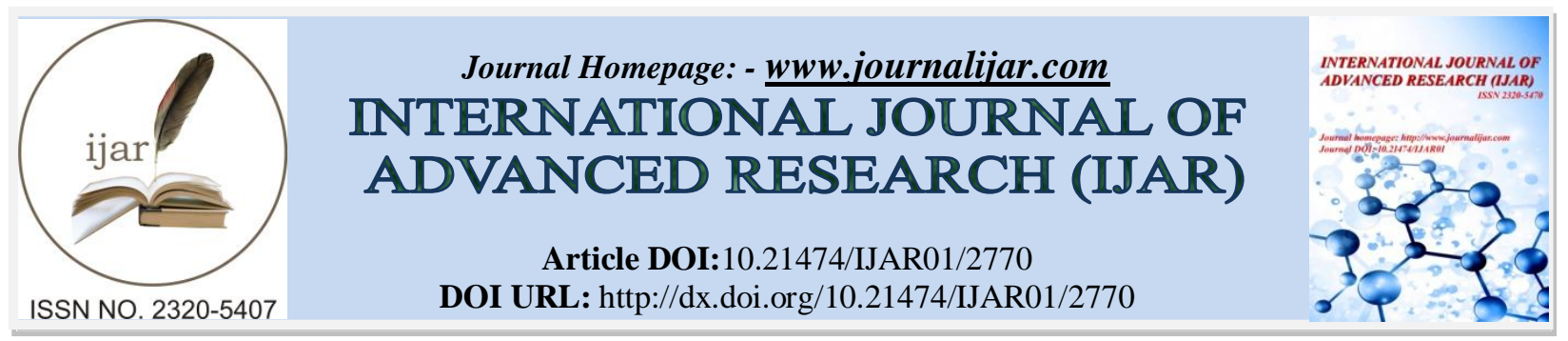

RESEARCH ARTICLE

\title{
A STUDY ON SCOPE OF EXTERNAL EQUITY FINANCE IN MSME UNITS IN INDIA.
}

Mr. Pr. Sreejith ${ }^{1}$ and Mr. P S. Anil ${ }^{2}$.

1. Pursuing MBA Finance and Marketing, Gnanam School of Business, Thanjavur.

2. Associate Professor, Gnanam School of Business, Thanjavur.

\section{Manuscript Info}

\section{Manuscript History}

Received: 15 November 2016

Final Accepted: 17 December 2016

Published: January 2017

Key words:-

External equity, MSME, Funds, Loan

Finance and Economic Growth.

\section{Abstract}

The Micro, Small and Medium Enterprises are back bone of the India. They contribute the significant amount to the GDP. They are located equally in both urban and rural areas and it provides high employment. So the governments also taking many actions to the growth of the MSME sector. Even though, the MSMEs in India are still struggle to survive, most of the MSME run loss or very smaller profit. The key issue of the MSME sector is funding. They cannot be able to raise as much funds from public for meet out their requirements. The MSMEs are mainly depend on the debt from other sources rather than banks. Now the MSMEs have many alternative sources to raise the funds. In that sources the external equity is one of the important sources to raise the investment. They have own advantage while considering other sources of finance. It is one of the less used sources of finance by the MSMEs. It is most suitable finance source to the MSMEs. The equity finance will help to avoid some of the major drawbackslike repayment, fixed interest payment of the MSMEs for raising and using of funds.

Copy Right, IJAR, 2016,. All rights reserved.

\section{Introduction:-}

The Micro, Small and Medium Enterprises (MSME) plays a vital role in the economic and social development of the country. They often act as a nursery of entrepreneurship. They also play an important role in the development of the economy with their flexible, effective, efficient and innovative entrepreneurial spirit. The Micro, Small and Medium Enterprises (MSME) sector has been a significant contributor to the country in the stream of generating the highest employment growth and it also accounts for the major share of industrial production and exports.

Micro, Small and Medium Enterprises (MSME) fuels the economic growth across the globe and they are the key instruments for promoting equitable development. The primary attribute of the sector is its employment potential at low capital cost. The labour intensity space of Micro, Small and Medium Enterprises (MSME) are much higher than that of large enterprises. Micro, Small and Medium Enterprises accounts for about 90 per cent of total enterprises in most of the economies. On the domestic front, MSMEs play an essential role in the overall industrial economy of the country. In recent years, the MSME sector has been consistent in registering a higher growth rate compared with the overall industrial sector. Further with qualities such as agility and dynamism, the sector has shown admirable innovativeness and adaptability to survive the recent economic downturn and recession.

Corresponding Author:-Mr. Pr. Sreejith.

Address:-Pursuing Mba Finance and Marketing, Gnanam School of Business, Thanjavur. 
The Indian Micro, Small and Medium Enterprises (MSME) sector space is immensely heterogeneous with regards to the size of the enterprises, variety of products and services, and levels of technology. The sector not only plays a crucial role in providing employment opportunities at comparatively lower capital cost than large industries but also helps in industrialization of rural and backward areas, reducing regional imbalances and assuring more equitable distribution of national income and wealth.

The Micro, Small and Medium Enterprises (MSME) are now the backbone of India's industrial landscape. With about 40 million units employing around 100 million people, directly and indirectly, the sector is the largest job provider in the country. They contributes about 8 per cent to the GDP, has a share of 45 percent in the country's manufacturing output growth, and contributes 40 percent to the country's exports.

\section{Definition:-}

Definitions of MSME in accordance with the provision of Micro, Small \& Medium Enterprises Development (MSMED) Act, 2006 they are classified in two Classes:

Manufacturing Enterprises- The enterprises are engaged in the manufacturing or production of goods pertaining to any industry specified in the first schedule to the industries (Development and Regulation Act, 1951) or employing plant and machinery in the process of value addition to the final product having a distinct name or character or use.

The Manufacturing Enterprise are defined in terms of investment in Plant \& Machinery.

\begin{tabular}{|l|l|}
\hline Manufacturing Sector & \multicolumn{2}{|l|}{ Investment in plant \& machinery } \\
\hline Enterprises & Does not exceed twenty five lakh rupees \\
\hline Micro Enterprises & More than twenty five lakh rupees but does not exceed five crore rupees \\
\hline Small Enterprises & More than five crore rupees but does not exceed ten crore rupees \\
\hline Medium Enterprises &
\end{tabular}

Service Enterprises:-The enterprises engaged in providing or rendering of services and are defined in terms of investment in equipment.

\begin{tabular}{|l|l|}
\hline Service Sector \\
\hline Enterprises & Investment in equipment \\
\hline Micro Enterprises & Does not exceed ten lakh rupees: \\
\hline Small Enterprises & More than ten lakh rupees but does not exceed two crore rupees \\
\hline Medium Enterprises & More than two crore rupees but does not exceed five core rupees \\
\hline
\end{tabular}

\section{Classification of MSMEs by location (\%):-}

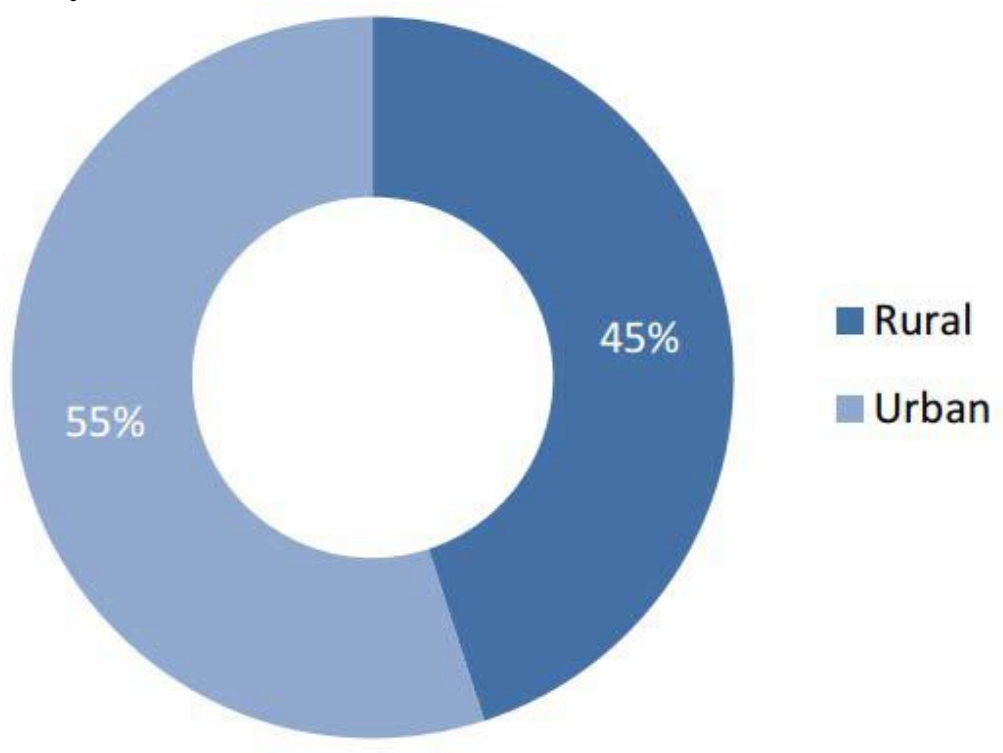


MSMEs have played an important role in the development of States in terms of the employment generation. More than 55 per cent of these enterprises are located in six major States of the country, namely, Uttar Pradesh, Maharashtra, Tamil Nadu, West Bengal, Andhra Pradesh and Karnataka.

The MSME sector has slowly come into the limelight, with increased focus from the government and other nongovernment institutions, corporate bodies and banks. Thechanges based on the policies, investments into the sector, globalization and India's growth story have giving several business opportunities for this sector.

According to this chart 55 per cent of MSMEs are located in urban areas of the country. But almost equal number $45 \%$ of about MSMEs are located in the rural areas. So the MSMEs in India playing a vital role in the development of rural areas and employment of rural peoples. Since India having more rural areas rather than the urban areas, the employment and development of rural peoples are more important to the development of the nation.

\section{Classification of MSMEs by sector (\%):-}

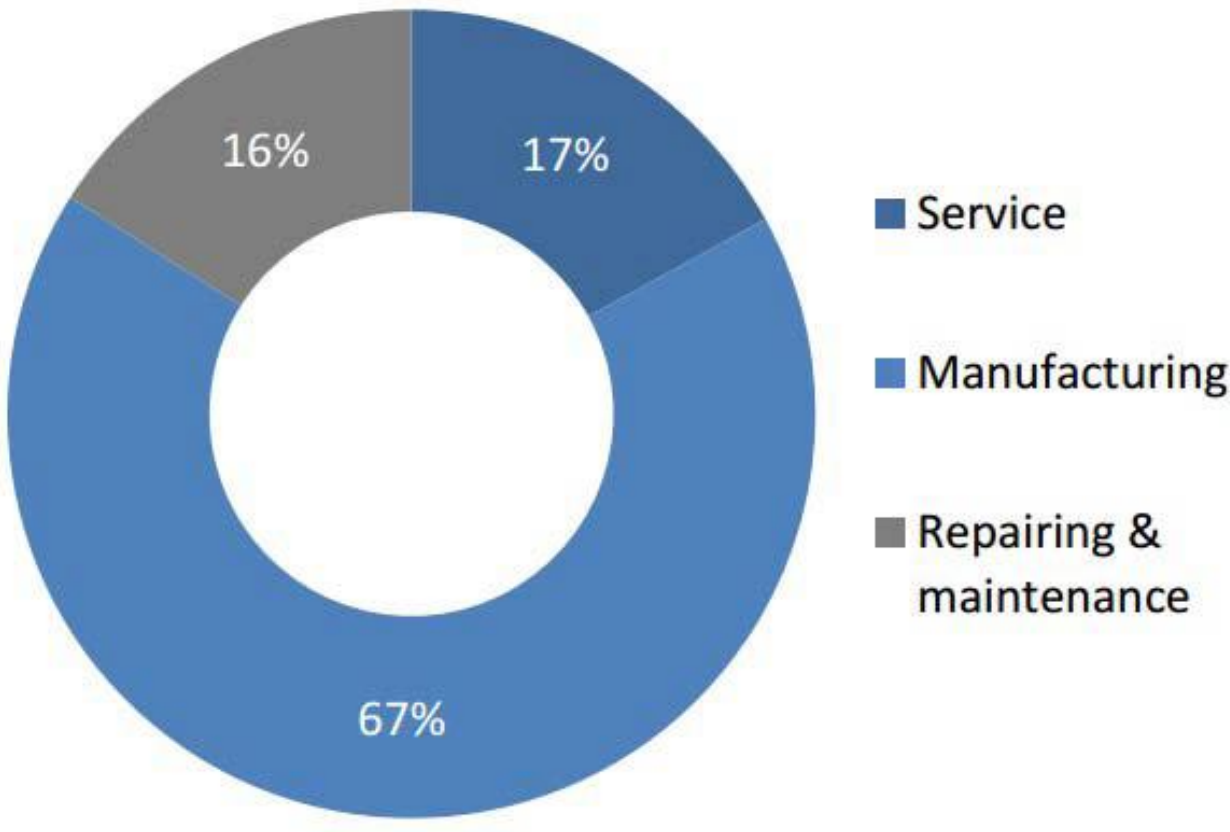

Indian MSMEs are mostly on the Manufacturing sector. The graph shows $67 \%$ of the Indian MSMEs in the manufacturing sector. The small manufacturing units are more important than the big manufactures in India because the small manufacturing units are contributing more in the economy rather than the big ones. After the manufacturing the Indian MSMEs are concentrating on the service sector. The 17 per cent of the MSMEs are in the service sector. The total Indian economy is concentrated more on the service sector but MSMEs are different in this case. They are more on manufacturing sector and lesser on the other sector sectors. It's a good sign to the government. Because now the government try to concentrate on manufacturing sector (E.g.:- Make In India program). The government can boost the MSMEs since they are more on manufacturing sector. For that the Indian government made many initiatives.

\section{MSME Funding - Challenges:-}

\section{Loan Finance:-}

The most dominant factor that stands as a hurdle to the MSME sector has been access to loan finance, sufficiently and timely. This problem is persistent despite clear instructions from the Reserve Bank of India (RBI) and the Ministry of Finance to encourage flow of funds from the commercial banks to small enterprises. It is examined that, there are strong structural underpinnings to the inadequate flow: the organizational structure of banks, and processes within them, have taken them far from task orientation, and have created a specific bias against small loan portfolios. With the proper guidelines and direction from RBI and an absence of performance-based incentive 
system for proactive bankers have all constricted easy flow of loan finance to small firms, it is much more difficult for tiny sectors.

It is observed that, transparency of the financial conditions of MSME is still lagging. This due to the lack of evaluation of the financial conditions by the owners themselves. This resultsin hesitation from banks to lend loan to small scale units. In fact, there is evidence to establish that a fairly significant proportion of loans given to small enterprises in the past have compounded the problem of non-performing assets (NPAs). Unless there is fairly detailed information on small firms, banks would hesitate to take risk. So to ensure transparency in decision on finance, loan finance is the alternate source.

\section{Issues in loan finance:-}

There are many issues and challenges that MSME's faces in getting loan from financial institutions.

\section{Lack of Information:-}

The adequacy of information about the MSME borrowers is the real problem for decision-making by banks in the lending process. Where information asymmetry exists, lenders may respond by increasing lending margins to levels in excess of that which the inherent risks would require. However, the low size of MSME lending makes it unviable for banks to invest in development of information systems about MSME borrowers. In such situations, banks may also reduce the extent of lending even when MSMEs are willing to pay a fair returns to them. The implication of raising interest rates and/or curtailing lending is that banks will not be able to finance as many projects as otherwise would have been the case.

\section{Granularity:-}

This is a situation where the risk grading system at banks does not have the requisite capability to discriminate between good and bad risks. This will lead to tightening of credit terms, or an increase in prices, or both. From the borrower's perspective, this leads to an outcome where the bank is over-pricing good risks and underpricing bad risks. The fact that most banks in India have not developed adequate expertise in MSME lending risk assessment exercises leads to the problem of granularity when it comes to MSME lending. Most banks in India are not having an effective risk assessment technique when it comes to MSME lending.

\section{Pecking order Theory:-}

This theory flows from the above mentioned issues that make MSME lending highly difficult for banks. Under this hypothesis, the sector which faces a cost of lending that is above the true risk-adjusted cost will have incentives to seek out alternative sources of funding. Evidence suggests that in such situations MSMEs prefer to utilize retained earnings instead of raising loans from banks.

\section{Moral Hazard:-}

Loans even though provided by banks to the MSME's the owners of the companies preference goes towards getting finance through other sources. One reason for this situation is that the owner of the firm benefits fully from any additional returns but does not suffer disproportionately if the firm is liquidated. This is referred to as the moral hazard problem, which can be viewed as creating a situation of over-investment. The moral hazard problem may thus lead to MSME lending turning bad in a short period of time, a situation that all banks would like to avoid.

\section{Switching Costs:-}

MSMEs may find it harder to switch banks, when countered with any issue. It is a known fact that the smaller the business, the more significant the switching costs are likely to be and, therefore, it is less likely that the benefits of switching outweigh the costs involved. This situation results in MSME lending becoming a seller's market, which may not be attractive to MSME borrowers.

\section{Alternative Financing:-}

\section{Securitization of Trade Credit:-}

The Trade credit is one ofthe source of financing for MSMEs, as they sell on credit to their large customers and then wait for long periods for payment. If these receivables (trade credit) could be packaged as a securitized asset, which would essentially be a commercial paper with the credit rating of the large firm, it could help MSMEs reduce their investment in working capital and their need for finance significantly. The credit worthiness of a typical MSME would also improve, qualifying it for greater bank funding. Though the securitization process which is similar to 
factoring, could be more cost-effective than bank funding, factoring, and letters of credit. But the Securitization of credit also depending on the borrowings.

\section{Angel Funds / Venture Capital Funds:-}

Angel investors are investors who typically invest their own funds, who manage the pooled money of others in a professionally-managed fund are increasingly becoming another alternative source of funding for MSMEs in India.

Venture/ Risk capital is often a more appropriate financing instrument for high-growth potential and start-up MSMEs. However, the ability of MSMEs (especially those involving innovations and new technologies) to access alternative sources of capital like angel funds/risk capital needs to be enhanced considerably. Although the sector commonly uses traditional debt, this type of financing is often not accessible for fast growth and start-up firms. During their initial phase, firms need finance to study, assess and develop an initial concept (seed phase) or for product development and initial marketing (startup phase). At this stage, firms may be in the process of being set up or may exist, but have yet to sell their product or service commercially. High-growth firms usually develop an idea, concept or product that requires an incubation period before generating revenues and profits.

\section{Private Equity Funding:-}

Private Equity (PE) investment provides another source of raising capital for MSMEs. Private Equity funds have been invested in Indian firms since 1990s. These financial enterprises are typically focused on funding a company early, adding value to them and making an exit at a later stage. They are stable sources of capital and tend to have an investment horizon of 3-5 years looking at a multiple return on their investment. Private Equity investors not only bring capital but also expertise and experience from established businesses and from the global markets. Private Equity companies will expect the portfolio of companies in which they are going invest should be best in practice. They also work extensively with their portfolio companies and encourage management to undertake operational improvements in case of any strategic opportunities such as mergers, acquisitions and joint ventures. The Planning Commission recently released a preliminary approach paper regarding its 12th five-year plan (2012-2017). A key focus area in the plan is to promote equity investment in MSMEs by constituting a Working Group devoted to the concept.

But the inclusion of private equity leads to some problems. The private equity investors will demand larger share of the business. So the existing owner will lose their ownership power and also their control on the business.

\section{Mezzanine Financing:-}

Mezzanine refers to hybrid financial instruments that possess characteristics of both debt and equity. It lies somewhere in the midst of debt and equity on the risk-return spectrum. In the hierarchy of creditors, mezzanine debt is subordinate to senior debt but ranks higher than equity. Mezzanine financing, usually completed with little due diligence on the part of the lender and little or no collateral on the part of the borrower, it is treated like equity on a company's balance sheet. Mezzanine debt is also called subordinated debt or second mortgage. Commensurate with their subjugated position in the claim over the assets of a corporation which is tantamount to the assumption of relatively higher risks, mezzanine financers typically demand a higher rate of return as compared to debt providers but lower than that required by equity investors.

Mezzanine financing requiresthe business owner to give up some measure of control over the firm. Business owners who agree to mezzanine financing may be forced to accept restrictions in how they spend their money in certain areas of the business. It is more expensive compare to the other traditional debt arrangements and arranging the Mezzanine finance is a lengthy process.

\section{Role of capital in MSME sector:-}

The challenges faced by Micro, Small and Medium Enterprises (MSME) sector arise from many areas. These enterprises are small in sizes have limited ability to withstand any economic problems. They are generally running with inadequate amount of capital. A large number of enterprises depend completely on the owner's capital and borrowing from individuals, without borrowing funds from financial institutions. It naturally inhibits their potential to grow their businesses. Many of the concerns of this sector like low technology level, lack of product variants, inability to increase manpower etc. cannot be addressed without adequate and timely availability of credit. It is only when these enterprises are adequately funded. Also, these enterprises often being the suppliers of larger enterprises suffer from the problem of the realization of payments for their products or services. These issues make pressure on 
their working capital which impacts severely their operations. Therefore, in the one hand they have limited capital to invest in fixed assets to expand their operations; on the other hand, due to lack of adequate working capital they find it difficult to continue their existing operations. The concerns are not confined to issue of credit availability; it's also about cost of credit. If the cost of credit cannot be made attractive for the borrowers of this sector, loan disbursal cannot be improved. The MSME sector, therefore, urgently needs more capital at a reasonable cost. The availability of funding can help it to address some of its key concerns. It needs more seed capital to start new ventures. Long term capital is needed to help the enterprises to invest in infrastructure in terms of land, plant \& machinery, technology sourcing etc. and to augment its operations. Working capital is required to ensure the running of day to day operations of the business. The flow of funds is critical for the survival and growth of MSMEs in the present competitive market. Not only these firms need debt financing, the growth cannot take place without equity financing. There is a possibility of growing firms taking only bank finance, getting over-leveraged. At that point further bank financing is hard to get. Therefore, the MSMEs can grow by having the access to both debt financing and equity financing options.

\section{Equity Finance:-}

Equity financing is the process of raising capital through the sale of shares in an enterprise. Equity financing essentially refers to the sale of an ownership interest to raise funds for business purposes. So the MSME have an option to raise the funds through Equity or issuing of shares.

Access to Equity Capital through SME Exchanges: Access to equity capital from the stock market is a genuine problem for MSMEs. Till some years ago, there was no great flow of equity capital into this sector. Absence of equity capital poses a serious challenge to the development of knowledge-based industries, particularly those promoted by the first-generation entrepreneurs with the requisite expertise and knowledge. Further, for efficient capital structure decisions, an optimal mix of equity and debt is very important. Keeping this in mind, the Report of the Task Force on MSME Chairman (Shri. T.K.A. Nair, 2010) had recommended the setting up of a dedicated Stock Exchange/Platform for MSMEs to access institutional and retail capital. This would also facilitate greater financial inclusion in the country. Following this, SEBI laid down the regulatory framework for the SME Exchanges with relaxed listing conditions and accorded approval to BSE and NSE to launch an SME Exchange in September 2011 and October 2011 respectively. Successful examples of SME Exchanges across the World include AIM (London), Canada (TSXV), Hong Kong (GEM), Japan (Mothers), Korea (KOSDAQ) and US (NASDAQ).

In March 2012, both BSE and NSE launched their SME exchange platforms to enable MSMEs to raise funds and get listed as public entities. BCB Finance Ltd. was the first Indian SME to get listed on the BSE SME Exchange. This was an event of immense significance for MSMEs as they have a huge listing potential but mostly had debtfinancing options. The launch of SME exchanges will play an important role in growth of MSMEs and the need of the hour is to improve the awareness among MSMEs about equity capital, stock markets and funding options, other than banks. The capital markets can play a crucial role in helping MSMEs improve their visibility and raise capital for their growth and expansion, offering an effective way to improve financial inclusion. They can also offer investors opportunities to invest in growing businesses at an early stage. Since its launch in March 2012, 13 companies have listed with BSE SME exchange, and BSE is negotiating with other companies for listing. BSE's rival NSE has also followed suit and launched its own SME platform called 'Emerge' with the proposed listing of Chennai-based SME Thejo Engineering. A vibrant equity market for MSMEs would also provide an added incentive for private equity and venture capital investments by providing an exit option for them. Listing on exchanges will also offer MSMEs an opportunity to offer equity ownership to their employees, thereby, increasing their commitment to their company and working for its future success.

The MSME sector is an important factor for growth of the country's economy, and presents a significant business opportunity for both banks and alternative finance providers. The improvements of financial exclusion in MSMEs is high and in spite of the increase in credit outstanding in recent years, fetching the adequate and timely credit from a bank is still a critical problem faced by the Indian MSME sector. So the alternative sources of finance can step in and assist MSMEs in their growth and development. In recent years, the amount of alternative finance options have improved and have proven to be an important source of financing for Indian MSMEs. The alternative financing avenues discussed above truly have the potential to bridge the financing gap for MSMEs from banks. Access to finance is essential for improving MSMEs competitiveness, as MSMEs have to invest in new technologies, skills and innovation. On their part, the MSMEs should be responsible borrowers, should use the finance in a judicious manner and take advantage of the business opportunities both within and outside the country. They should improve 
their governance and risk management practices, maintain proper books of accounts, submit correct information to banks and all authorities, and make their operations more efficient and productive to get easier access to finance from banks and other investors. This way the MSME sector would become more competitive and efficient and contribute further to the economic development of our country.

\section{Equity Demand:-}

Figure 19: Viable and Addressable ${ }^{[55]}$ Equity Demand in MSME Sector (in INR trillion)*

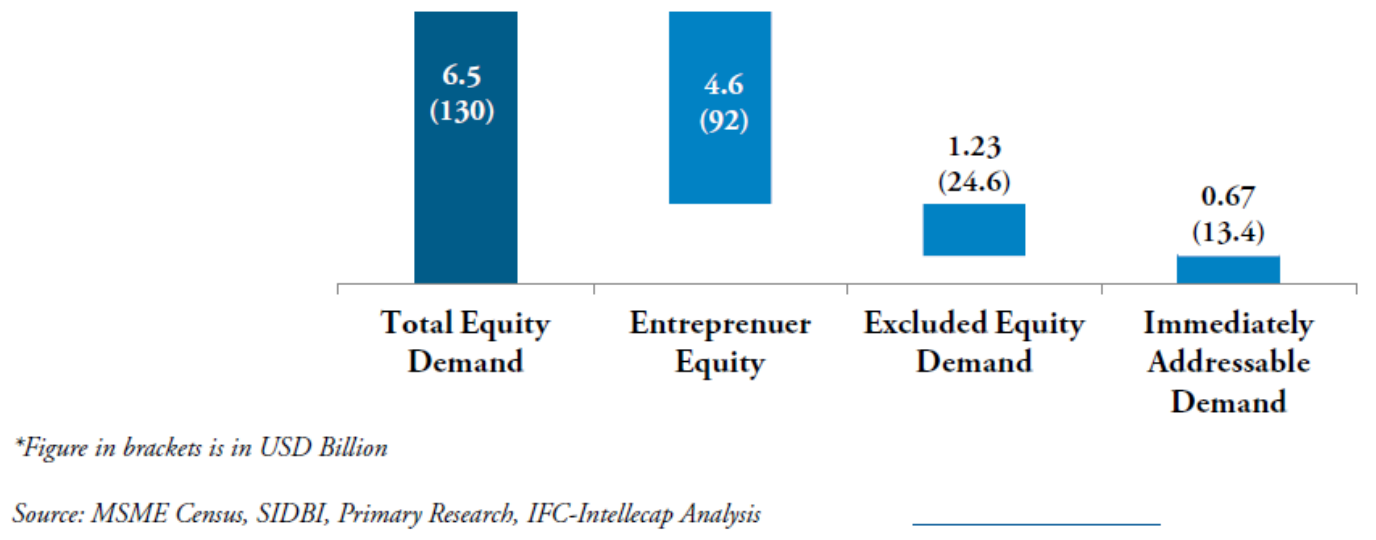

The picture shows the overall equity demanded by the MSMEs are 6.5 trillion rupees. In the total demand 71 per cent (4.6 trillion) contributed by the entrepreneur or the real one owner of the firm. The MSMEs are demanded the 1.23 trillion rupees excluded equity. The graph clearly shows that the Indian MSMEs are more depend on the Entrepreneur equity. The most of the MSMEs in India running with depending more on the individual owner's money and borrowed capital.

Small Size of Equity Investments in the MSME:-

\begin{tabular}{|l|c|}
\hline Enterprise & $\begin{array}{c}\text { Average Investment Size } \\
\text { (in INR Million) }\end{array}$ \\
\hline Micro & $0.04-0.05(800-1000)$ \\
\hline Small & $0.3-0.5(6000-10,000)$ \\
\hline Medium & $7-10(0.14-0.2$ Million) \\
\hline
\end{tabular}

* Figures in bracket in USD; Source: IFC - Intellecap Analysis

Micro and Small Enterprises have less access to external equity initially because only low number of players supplying early-stage equity capital. If the equity were made available, the absorption would remain low because of:-

a. Legal structure of enterprises that prevent infusion of external equity;

b. Low level of willingness and ability of entrepreneurs to manage formal sources of equity capital

c. Entrepreneur's concern regarding control and management. 
However, the equity demand from small enterprises that have legal structures other than proprietorship and partnership is considered as viable and addressable in the near term.

Medium-scale enterprises have a more balanced debt-equity ratio (2:1). It is maintained because of the high ability of the entrepreneur to invest in capital. The debt-equity ratio maintaining through the high levels of contribution of the individual owner of the firm.

Equity Demand in Early-Stage and Growth-Stage Enterprises:-

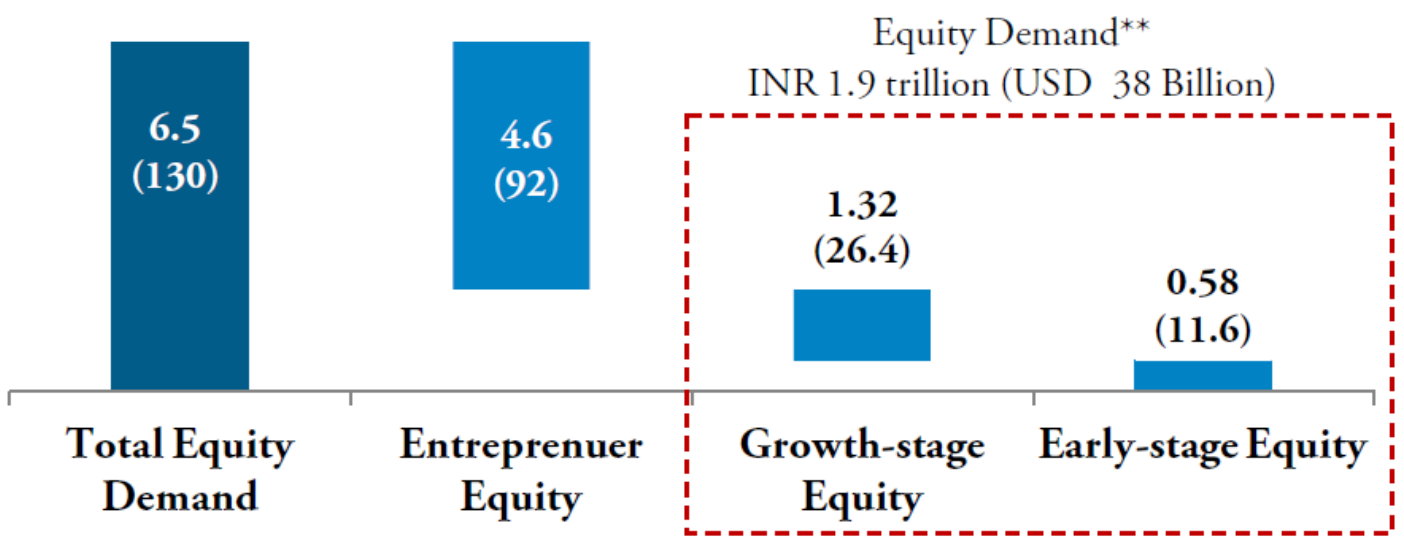

*Figure in brackets is in USD Billion
**Includes equity demand by micro enterprises
Source: MSME Census, SIDBI, Primary Research, IFC-Intellecap Analysis

Early-stage enterprises are defined as those that have an operational history of one-year or less. Their equity demand is very less compare to the Growth stage enterprises. The total equity demanded is 1.9 trillion, in that 1.32 trillion demanded by Growth-stage equity enterprises. The balance will demand by the Early-stage equity enterprises.

\section{Benefits for MSME Using External Equity:- \\ Permanent Source of Finance:-}

One of the permanent solution for finance needs of an MSME is equity financing. No company's main focus or objective can be financial management only. If one organization raise the funds from borrowings. But they should repay the debt amount over a period of time. But the equity finance never be repay because it do not have any maturity period. Equity finance provides that leverage to the management to continuously focus on fulfilling their core objectives. It keeps management away from the hassles of raising funds again and again like other sources of financing. So the MSMEs do not worry about the maturity period of the raised funds and repayment of them.

\section{Retained Earnings:-}

If company having the external equity finance in their capital structurethrough that they can develops an internal source of finance. The earnings which a company generates using the capital can be retained with the company to finance the increased working capital and other fund requirements. The company can effectively achieves its objective of shareholder's wealth maximization by the way of using this funds in projects with higher returns compared to what is available to the equity shareholders. Through the retained earnings the MSMEs can rise more funds with less expenses.

\section{Dividend Payments:-}

Equity finance for a new company is like the blessings of an angel. The main limitation of a new company is the uncertainty of cash flows. No fixed obligation to pay dividends will help to avoid the problems arising from the uncertainty of cash flows. A company can choose to pay no dividend or smaller dividends as per the earnings of the company. It help to the MSMEs to avoid the burden of monthly payment of higher interest rates for other raised funds. 


\section{Less burden:-}

Using equity finance, there is no loan to repay. This offers relief in several ways. First, the business doesn't have to make a monthly loan payment. This can be particularly important if the business doesn't initially generate a profit. This also frees you to channel more money into growing the business.

\section{Challenges for MSMEs in Equity Infusion:-}

The legal structure will influence the ability of an enterprise to accept external equity funds. The investors can invest in the firms through that the enterprise will be extent their liability is limited to their respective shareholding in case of Limited companies and limited liability partnerships. In the case of proprietorship and partnership transfer unlimited liability to the equity investor, hence discouraging equity infusion in such enterprises.

Approximately 96 percent of MSMEs in India are proprietorships or partnerships. Because of that the MSMEs can't able to attract external equity. While change in the legal form of an enterprise to limited company or limited liability partnership is an option, it entails taxation and compliance overheads for the enterprises, often rendering the business model financially unviable. Most of theentrepreneurs do not havemuch awareness of alternative sources of finance. So the benefits of changing their legal structures are not always obvious. Limited presence of external equity, entrepreneurs use informal sources (usually debt) to meet the needs of their enterprise.

Most of the mature small enterprises andmedium enterprises which are able to keep their financials transparent, and tend to attract more equity investors. Also, the legal structure of mature small enterprises and medium enterprises allows for inclusion of external equity. It is because the external equity investors expects transparency in both financial record-keeping and governance.

\section{Conclusion and Suggestions:-}

The growth of MSMEs sector in India is far reaching. The government special programs to develop this sector are stronger.

The central government of India has a separate minster to take over the MSME sector. Which makes the sector more powerful. Because they can make separate programs for the development of the MSMEs in India.

The real drawbacks of Indian MSMEs are insufficient funds. MSMEs can't able to raise as much funds to invest and develop.Indian MSMEs are raising funds by way of debt. For this also they not getting much assistance from banks. So the MSME owners are focus on other debt sources apart from the banks. The banks also do not have enough information about the MSME organizations to provide the loans. Because the MSMEs are mostly failed to keep their records correctly.

Another important sources of funds are single owner investment. According to the capability of the owner can contribute the funds to the organization from his wealth (equity). So, mostly Indian MSMEs are depending on single owner funds and Debt.

The use of external equity is one of the finest solution to the Indian MSMEs for the issues of raising funds. But it is the one of the less used way of fund raising by the MSMEs especially micro enterprises.Using external equity in the capital structure will help to the MSMEs to avoid some key issues faced by them. The issues are like fixed monthly payment of the interest amount, Repayment of the raised amount and problems of paying return to the investors if the firm get losses in initial stages. The organization need not to pay the dividend if they get loss.

The MSMEs get another fund raising option called retained earnings. They choose less or no dividend payment option. This will give another pool of funds to further more growth of the organization. The investors also happy because the value of their share will go up through the growth of the organization.

The Indian MSMEs are have great opportunities to raise the funds through the external equity. For that the main Indian exchanges BSE and NSE are opened the particular platform. So the Indian MSME owners also should take some initiatives to grab this opportunity. 


\section{Reference:-}

1. International Financial Corporation- "Micro, Small and Medium Enterprise Finance in India" A Research Study on Needs, Gaps and Way Forward (November, 2012)

2. Biswajit Bose - "Financing of Micro, medium and small scale enterprises in India Key Challenges" -Volume 1, Issue 1 (May. - Jun. 2013), PP 01-04

3. Report of Prime Minister's task force on Micro, Small and Medium Enterprises, Govt. of India, January, 2010.

4. Vision 2020: Implications for MSMEs (2011), Grant Thornton, FICCI.

5. Chakrabarty K.C. (June, 2010). Bank Credit to MSMEs: Present status and way forward, RBI monthly Bulletin.

6. Annual Report, (2014-15). Ministry of Micro, Small and Medium Enterprise, Government of India.

7. Badulescu Daniel. SMEs Financing: The extent of Need and the Responses of Different Credit Structures.

8. Final Report (Edition: April, 2011) 4th All India Census of MSME, 2006-07: Registered Sector.

9. Risk Capital and MSMEs in India (A SIDBI Publication).

10. Resurgent India Limited - MSME Funding - Opportunities \& Challenges.

11. Business line, (June 8, 2011), Challenge of financing SMEs.

12. Government of India Ministry of MSME - MSME Schemes

13. https://efinancemanagement.com/working-capital-financing/disadvantages-of-trade-credit

14. PricewaterhouseCoopers Private Limited - Financing for MSMEs the eastside story

15. Ayyagari, M., Beck, T., and Demirgüç-Kunt, A., 2007. Small and Medium Enterprises across the Globe. Small Business Economics 29, 415-434.

16. Balling M, Bernet B and Gnan E. Financing SMEs in Europe, SUERF-The European Money and Finance Forum, Vienna, 2009.

17. Financialexpress, (February 27, 2015), Options in MSME financing.

18. Bebczuk RN. What determines the Access to Credit by SMEs in Argentina, Documento de TrabajoNro, 2004, $16(1)$.

19. Dr. Ram Jass Yadav, Issues in SME Financing.

20. Beck, T. and Demirgüç-Kunt, A., 2006. Small and Medium-Size Enterprises: Access to Finance as a Growth Constraint. Journal of Banking and Finance 30, 2931-2943. 